\title{
The Web as an Alternative Communication Resource for Pro-Biafra Independent Movements in Nigeria: The Case of Indigenous People of Biafra
}

\author{
By Emmanuel Sunday Nwofe ${ }^{*} \&$ Mark Goodall ${ }^{\dagger}$
}

\begin{abstract}
The web has become an important platform for social Movement communication. This paper seeks to: (1) examine the extent to which the IPOB Movement, one of the prominent social Movements in Nigeria, appropriates its websites to communicate oppositional interpretations and discourses that capture the essential essence of its struggles for Biafran Independence; (2) assess the communication practices on the websites and the extent to which they enhance the capacity of the Movement to advance its cause, counter anti-Biafra propaganda and challenge State oppression; (3) empirically analyse patterns of communication practices of the web and provide a theoretical connection to how the Movement's websites contribute to building a radical democratic public sphere in Nigeria. The results show that a mix of alarm and outrage with trolling mechanism were significant repertoire of resistant communication by which the Movement walked itself to the frontline of public discourse in Nigeria's public sphere. It is found that the websites (1) provided information relevant for micro mobilisation; (2) serve as a hub for native reporting and radical content production and (3) serve as a channel for documenting graphic evidence of victimhood and contestation of issues relating to the Nigeria democracy and Biafra independent struggle. However, the study notes a varying degree of focus in the main agenda of the Movement, which is mobilising support for referendum to determine Biafran union with Nigeria. The paper concludes that although the websites serve as a hub for circulating oppositional interpretations of events which are of interest to the Movement, there is limited evidence to suggest communication of articulate objective of the Movement for observers' evaluation. The implication of this for African social movements is discussed.
\end{abstract}

Keyswords: alternative media theory, Biafra movement, internet communication, IPOB websites, radical democracy, social movement.

\section{Introduction}

One of the most prominent pro-Biafran Movements, the Indigenous People of Biafra (IPOB) Movement is remarkable in the extent to which digital media technology played a central role in its organisation and mobilisation. The IPOB is a secessionist Movement, which seeks to break away from Nigeria and form an independent nation of Biafra. This plan is not new. On May 30, 1967, Igbo ${ }^{1}$ leaders declared a Biafran state, which led to a brutal civil war that ended on January 15, 1970 (Onuoha, 2018). Nevertheless, the idea of Biafra separatism has continued to ferment, leading to several secessionist Movements in the past. The IPOB is currently the most prominent Movement in the line of Movements taking

\footnotetext{
*Research Student, University of Bradford, UK.

'Senior Lecturer, University of Bradford, UK.

${ }^{1}$ The Igbo is the third most dominant ethnic group in Nigeria, native to the present-day of south-central and southeastern Nigeria.
} 
up the cause. The Movement wants the Nigerian government to organise a referendum in the style of the British's "Brexit" referendum, to determine whether the people of Biafra still want to remain in Nigeria.

The digital media activities of the Movement came to prominence in 2015, following the arrest and incarceration of its leader, Mr Nnamdi Kanu, a British Nigerian, by President Mohammadu Buhari. Prior to his incarceration, Mr Kanu, through his radio Biafra FM transmissions from London, repudiated in strong words the alleged lop-sidedness of Nigeria's socio-political structures, double standards and lawlessness. The arrest of Kanu exacerbated pro-Biafra consciousness among the ethnic Igbos, culminating in widespread protest Movements within Nigeria and many countries of the world, including the UK, US, France, Italy, Germany, Malaysia etc. Through digital activities of the Movement, Biafra became a metaphor for discussing national leadership failure and a symbol of a collective aspiration to restructure Nigeria into a representative democracy. The Movement's heavy reliance on the Internet to keep afloat the evidence of political marginalisation resonated within its constituency, where prominent politicians and stakeholders have begun to identify and lend their influence to the Movement, in order to retain their legitimacy with the people. The Movement utilised an ecology of Internet resources, one of which is the web, for mass education and mobilisation. Various commentators have argued that the Internet, and especially the web, provides an effective form of activist media, wherein activists counterbalance the dynamic of mainstream media reporting, which, in their view, disregards the broader context of protest Movements (Atton, 2004; Lievrouw, 2011; Wall, 2003). The Internet can play a variety of roles for social Movement organisations, including the provision of information, assisting in action and mobilisation, promoting interaction and dialogue, enabling literal linkages as well as promoting fundraising and resource generation (Stein, 2009, pp. 752-753). While some scholars have argued that the Internet promotes a deliberative communicative public sphere in the Habermasian perspective (Salter, 2013), by which citizen deliberation can lead to the formation of a rational public sphere, Dahlgren (2005) argues that such theorisation fails to account for what defines legitimate deliberation. As such, a social Movement media can espouse "discursive radicalism" and inter-discursive conflict" (Dahlgren, 2005, p. 47) that can affect its success or failures. In the context of the IPOB Movement, it is interesting to ask if the Movement's alternative media contributed to understanding Biafra independence struggle, or just the lived realities of apparent marginalisation and exclusion of the people that walks the Movement to the frontline of political activism in Nigeria. The purpose of this paper is to: (1) examine the extent to which the IPOB Movement appropriated its websites to communicate oppositional interpretations and discourses that capture the essential essence of its struggles for Biafran Independence; (2) assess the communication practices on the websites and the extent to which they enhance the capacity of the Movement to advance its cause, counter anti-Biafra propaganda and challenge state oppression; (3) empirically analyse patterns of communication practices of the web and provide a theoretical connection to how the Movement's websites 
contribute to building a radical democratic public sphere in Nigeria. Specifically, the paper poses the following questions:

1. How does the IPOB Movement use the web to communicate primary collective issues?

2. To what extent does the IPOB Movement use the web to counter antiBiafra information, advance its cause and challenge state oppression?

3. How do the IPOB websites contribute to building agonistic radical democratic politics in Nigeria's public sphere?

Drawing mainly on alternative and radical democratic theories, this paper offers additional insights into African social movements and the use of the Internet. It further brings into focus the text-based communication elements that explain variations in how social Movements in Africa communicate grievances online in the context of IPOB. By assessing the linguistic and discursive mechanisms under which activists interpret grievances, the paper contributes to an understanding of "activists-centred layer" of Internet use that can enrich the understanding of the Internet as a site of struggle. Such an approach of rhetorical analysis contributes to a better understanding of Movement's communicative phenomena on the web (Schneider \& Foot, 2004)

\section{Literature Review}

\section{The Theoretical and Empirical Backdrop of Social Movements Communication in the Mass Media}

The rise of protest Movements and the contributions of digital media have inspired both academic and public attention to the dynamic relationships between social Movements and their medium of communication. Commentators have described social Movements as key platforms by which to raise discreet social and political issues, which the market and states have elected to keep secret (Stein, 2009). Hence, the communication process is integral to their success (Atton, 2004; Evans, 2016). Research has shown that communicating through the mainstream media has become especially dialectic (Boykoff, 2006; 2013), as mainstream media focus on undesirable actions that affect a Movement's legitimacy in the public sphere. Boykoff (2013) identified five causal mechanisms by which the transactional interaction between state and mass media can "animate the process of social Movement demobilisation" (p. 5). One such mechanism is the "resignification process" by which mass media coverage can change the underlying beliefs that make up the discourses and frames used by Movement actors thereby shaping which set of beliefs are salient and " altering the meaning of actors" interest that generally affects the power of a particular discourse or frame" (Boykoff, 2013, p. 5). Movements can only get adequate mainstream media coverage if they employ dramatic or disruptive tactics, however, undesirable 
(Evans, 2016), because journalists have privileged "tactics" more than a Movement's goals (Boyle, McLeod, \& Armstrong, 2012).

Consequently, communication scholars have suggested that the Internet constitutes a crucial alternative resource for social Movement's communication (Atton, 2004; Lievrouw, 2011), providing communication opportunities not available in the mainstream media or alternative form of Movements' media (Castells, 2015) and creating "emancipatory communication practices" that challenge dominant powers in the communication and media field (Akser, 2015, p. 2). Social Movements can rely in large measure on networked communication technologies to organise and disseminate alternative information that supports their objectives (Conover et al., 2013). Not only that, social Movement can bypass mainstream gatekeeping and communicate directly with their constituents and the broader public. However, the cost of doing so is also possibly reduced (Garrett, 2006). Moreover, the Internet can facilitate the transnational character of Movements, by "effectively and rapidly diffusing communication and mobilisation efforts" across borders (Van Laer \& Van Aelst, 2010, p. 1146). With the proliferation of social media, social Movements are much more obligated to produce issue-based content with which to meet increasing public expectations to access information from Movement's sources (Harlow, 2012), or to provide conflict early warning signals to government.

While contemporary research has largely focused on the role of social media as an alternative platform for communicating social activism (Enjolras, SteenJohnsen, \& Wollebæk, 2013; Gerbaudo, 2018; Sandoval-Almazan \& Gil-Garcia, 2014), scholars have failed to represent much clearly the importance of websites in the contemporary social activism. In other words, social Movement literature still offers thin descriptions of the actual communication practices of Movements' websites, even when this is still of interest to those who theorise the political value of the Internet as a communication resource (Stein, 2009). Few available research has been " incremental and ad-hoc" (Earl \& Garrett, 2017, p. 479), with analytical toolbox that "does not include a systematic theorising of the communicative side of social unrest" (Mattoni, 2017, p. 495). Furthermore, social Movement literature has not offered much description on how contemporary social Movements in Africa are using the websites as communication resource, much less Nigeria. Websites are complex platforms that go beyond text in their appeals, incorporating other technologies and software applications such as video, audio, images, graphics and instant chat that favour horizontal and participatory communication and dissemination of information. Social Movements' websites can provide capacity for activists and bystanders to search and retrieve archived information, which can enhance the continuity of collective action and discourses in the increasingly visual digital public sphere. It is of interest to understand their newscreation practices and analyse how such practices work to sustain oppositional culture and/or limit Movements' success in the broader public sphere. 


\section{The Internet as Alternative Media}

The Independent Media Centres (IMC), otherwise known as Indymedia, in the early 2000s, heralded a new type of media activism that sparked academic interest in alternative media, as well as the Internet as a platform for radical politics. Proponents of Indymedia claim that they provide an alternative to the agendas, politics, economics, reporting practices, and ethics of mainstream news organisations, and are thus the direct descendants of "alternative" or "radical" news media (Lievrouw, 2006, p. 5). In the literature, the definition of alternative forms of media is characterised by different interpretations. Some scholars prefer to employ different labels, such as "critical media" (Fuchs, 2010), "radical media" (Downing, 2000), "activist new media" (Lievrouw, 2011), or citizen media (Rodriguez, 2000). Whichever label depends on the locus of study and the emphasis a scholar wants to promote, but also denotes a strong relationship between alternative media and activism. In other words, alternative media play an important role in educating activists, promoting an oppositional interpretation of events of interest, mobilising constituents, prompting action and creating an identity (Rauch, 2007). The political motivation behind the development of such alternative spaces is to give activists and supporters the opportunity to express their concerns, show their interest and discuss local and global issues relevant to their struggles (Platon \& Deuze, 2003). Research has shown that it is an only alternative form of media that reports the strengths and legitimacy of social Movements, casting a positive light on activists as against the mainstream media, whose reports tend to be non-sympathetic (Cissel, 2012).

A great deal of critical discussion revolves around the Internet and the public sphere paradigm developed by Jürgen Habermas. With criticisms thereto, the Internet is thought to advance a public sphere of equal deliberation and pluralism, thus providing the resources for the "counter-public sphere" (Downey \& Fenton, 2003; Gimmler, 2001; Salazar, 2003).

The IPOB websites constitute an example of the counter-public sphere in the sense that they produce radical communicative interactions that diffuse into other channels of digital communication. Activists initiate most oppositional debates and discourses including the failure of leadership, inequitable political structures and the dictatorial approach of government to their struggles on the websites. Such media practice adds to enriching the debate about good governance, equality and justice in the Nigerian public sphere. Research has suggested that a lot of Movements are using digital communication platform's alternative resources for social activism (Harlow \& Harp, 2013; Poell, 2014; Poell \& Borra, 2012). Harlow and Harp (2013)'s analysis of activists' use of alternative media, suggests that activists were positive about the role of the Internet as an alternative public sphere for staying informed and for waging activism. In Chile, social Movement organisations have relied on hybrid alternative media ecology in their activism (Jofré, 2017). This is the same in Hong Kong, where Yung and Leung (2014) found the Internet as alternative media resources that encourage civil society activism, by facilitating and enlarging "active online counter-public" (Leung \& Lee, 2014 , p. 340). While alternative media can be said to offer a voice to the 
voiceless: "voice as a process and voice as a value" (Atton, 2015), it can be argued that it is not enough for the Internet to offer a voice to a social Movement, such a voice must carry concomitant value in the wider process of social change. In that perspective, we argue that while the websites can provide alternative communication resources for the IPOB Movement, it is expected that interactions should add value to the cause of the struggle, in ways that not only accommodate differences, but also promote the web as a platform for social mobilisation in Nigerian society.

\section{The Internet as a Radical Democratic Public Sphere}

The concept of radical and agonistic public sphere helps us explain the dialectic in online communications of the IPOB's websites. Specifically, the concept sheds light on the bitter, caustic, vituperative and unequivocal discourses, which characterise the Movement's web communication. Contrary to the model of deliberative democracy, which emphasises a strong link between democracy and liberalism - based on inclusive normative consensus or "communicative rationalism", the radical or agonistic perspective views politics as intrinsically conflictual and non-consensual, placing differences and contestation at the heart of the democratic system (Dahlberg, 2007a; Mouffe, 2000). Dahlberg (2007a) argues that counter-discourses emerge in response to exclusion. And so, fragmentation into like-minded groups allows for articulation and identification of issues, which have been excluded from, and thus stand in opposition to, dominant discourses. Such fragmentations, he argues, contribute to the plurality of counter-discourses that are beneficial to democracy.

Various commentators have argued that the Internet's contribution to democratic politics is mainly in the promotion of agonistic public sphere (Bennett \& Pfetsch, 2018; Dahlberg, 2007b; Dahlberg \& Siapera, 2007; Kellner, 1999). Agonistic public sphere is a model of democratic politics, which acknowledge the dimension of antagonism that the pluralism of values entails and its ineradicable character (Mouffe, 2000). This entails the expression of emotions, especially hatred, resentment, anger and compassion, both on the Internet and in the news media, by which conflicting interests are contested and paradoxes in society are exposed (Tong, 2015, p. 333). The agonistic public sphere considers the Internet's capacity to account for the democratic role of politics associated with excluded voices. In this line of argument, the emphasis is not how much individuals deliberate with differently positioned others. Instead, "the focus is on the formation of counter-discourses online and the extent and effects of inter-discursive contestation" (Dahlberg, 2007a, p. 839). Emphasis on the democratic role of contestations from a mainstream public sphere, which the Internet supports. In fact, the radicalness of agonistic pluralism lies in its aim to recognise differences and to ascribe rights, to reach out to as many friends as possible, while retaining the necessary contestation and sheer struggle of politics (Hands, 2007).

The IPOB activists espoused agonistic deliberation in different ways. First, their communication discourses are replete with rumours, abuses and stereotype. Second, they do not allow a nuanced argument around Biafran independence that 
crave for an informed debate. Instead, they tend to attack any contrary opinion to their approaches. Third, they promote narratives that do not account for the role of Igbo politicians in the situation they are in, blaming other ethnic groups in almost everything. Some authors argue that dispersion and cacophony of public voices have led to a "disruptive public sphere" that is unable to communicate across difference (Bennett \& Pfetsch, 2018). The Internet as a contested terrain allows for contentious claims and discourses to flourish in the public sphere, encouraging antagonistic politics to mushroom, as diverse group are able to voice dissentious opinion online. From the agonist literature, Dahlberg (2007b) summarised the role of Internet in supporting agonistic democratic politics. First, the internet support marginalised voices to "develop their own deliberative spaces that draw upon and strengthen marginalised discourses". Second, the Internet is deemed to help in "linking up with other excluded voices in developing representatives, strategically [facilitating] effective counterdiscourses". Third, the Internet contributes to subsequent "contestation of meanings and practices dominating mainstream public sphere".

\section{Methods}

In order to examine the dynamics of communication practices on IPOB websites, this paper adopted a web-based content analytical approach - a method that combines qualitative and quantitative approaches in analysing communication characteristics. First, the researcher identified the main websites used by the Movement by searching the links included on the Movement's blog www.ipob.org. Second, the researcher obtained additional information by interviewing activists as part of a larger research study examining the impact of new media technology on IPOB Movement. Ultimately, three online news platforms: Biafra Times, Biafra Herald and Biafra Telegraph were sampled based on their unique features, which will allow for the examination of archival information. Each website sampled has a link to archived publications and articles arranged according to the months of publication. The scope of the study was between October 2015 (when the Movement came to prominence following the arrest and incarceration of its leader) and April 2017 (when the leader was released on bail), a total of 20 months. The reason for this choice is that this period is the height of active and radical communication exchange between the Movement and the Nigerian authority and will allow for better understanding of the use of their websites to disseminate and share alternative and critical content and information. The homepage constitutes the unit of analysis. The reason for this is twofold. First, websites can contain hundreds of pages and thousands of textual and multimedia files which can pose a number of "unrealistically demanding" problems in coding (Ben Moussa, 2011). Second, a homepage constitutes the first point of entry in a website, possessing many central and organisational elements of web design that are "attention-grabbing" (Ben Moussa, 2011, p. 133). Furthermore, due to the potential of the web to accommodate a large number of textual items, the study 
adopted a purposive sampling of 15 items per month, resulting in 300 items per news source. Finally, 900 articles were analysed and coded.

\section{Coding}

Drawing on the topology of communication function as developed by Stein (2009), we coded and categorised the textual items according to issues they raised, while also focusing on the radicalism or otherwise of the communication content in terms of their value for mobilising social change. Following Saldaña (2015), which explains various coding methods, we further adopted the subsequent coding methods: Descriptive Coding (to note the topic written about); In vivo Coding (to note the specific qualitative evaluative feature of text); Narrative Coding (to note stories and how they are retold in the text); Evaluation Coding (to reflect on the nature and content of the inquiry); and "Theming data" (to capture the meaning of an aspect of data using phrase or sentence) (Adu, 2016). Thereafter, we sorted the codes based on their relationship and frequencies, and synthesised them under four main categories: 1) whether communication provides information; 2) whether the text communicates injustices; 3 ) whether communication creates an identity, or 4) whether communication prompts action (action and mobilisation). In each main category there are sub-categories, which further highlights the specific issues of interest in the Movement's media practice. The codes generated by activists' communication content were slightly modified, which suggests its reliability. We attained additional reliability check by the agreement of two coders: the researcher and another research student.

\section{Results and Discussion}

\section{Quick Summary}

In a quick summary, Table 1 shows that information variables were mostly reported, followed by variables promoting action or mobilisation. Variables on identities were less reported.

Table 1. Case-Processing Summary

\begin{tabular}{|l|c|c|c|c|c|c|}
\hline & \multicolumn{3}{|c|}{ Cases } \\
\cline { 2 - 7 } & \multicolumn{2}{|c|}{ Valid } & \multicolumn{2}{c|}{ Missing } & \multicolumn{2}{c|}{ Total } \\
\cline { 2 - 7 } & $N$ & $\%$ & $N$ & $\%$ & $N$ & $\%$ \\
\hline IPOB Websites * Information & 309 & 34.3 & 591 & 65.7 & 900 & 100.0 \\
\hline IPOB Websites * Injustice & 232 & 25.8 & 668 & 74.2 & 900 & 100.0 \\
\hline IPOB Websites * Identity/Culture & 71 & 7.9 & 829 & 92.1 & 900 & 100.0 \\
\hline IPOB Websites * Action \& Mobilisation & 288 & 32.0 & 612 & 68.0 & 900 & 100.0 \\
\hline IPOB Websites * Linguistic Tone & 900 & 100.0 & 0 & 0.0 & 900 & 100.0 \\
\hline
\end{tabular}




\section{Information: Alarms as Repertoire of Resistant Communication Strategy}

The analysis demonstrates a cross-mix of information on the websites. Our Initial coding produced eight themes under which the Movement used the web to provide diverse information (Table 2).

Table 2. Thematic Components of Information * IPOB Websites Cross Tabulation Count

\begin{tabular}{|l|c|c|c|c|}
\hline \multirow{2}{*}{} & \multicolumn{3}{|c|}{ IPOB Websites } & \multirow{2}{*}{ Total/(\%) } \\
\cline { 2 - 4 } & $\begin{array}{c}\text { Biafran } \\
\text { Telegraph }\end{array}$ & $\begin{array}{c}\text { Biafran } \\
\text { Herald }\end{array}$ & $\begin{array}{c}\text { Biafran } \\
\text { Times }\end{array}$ & \\
\hline Incompetence/Abuse of Office & 28 & 19 & 28 & $\mathbf{7 5 / ( 2 4 . 3 )}$ \\
\hline Raising the Alarm & 18 & 26 & 19 & $\mathbf{6 3 / ( 2 0 . 4 )}$ \\
\hline $\begin{array}{l}\text { Inaccurate Reporting, Propaganda/ } \\
\text { Media Silence Conspiracy }\end{array}$ & 10 & 19 & 15 & $\mathbf{4 4 / ( 1 4 . 2 )}$ \\
\hline Ineffective Representation & 9 & 13 & 16 & $\mathbf{3 8 / ( 1 2 . 3 )}$ \\
\hline $\begin{array}{l}\text { MNK, IPOB Leadership \& } \\
\text { NeoBiafranism }\end{array}$ & 9 & 10 & 9 & $\mathbf{2 8 / ( 9 . 1 )}$ \\
\hline International Conspiracy/Silence & 8 & 7 & 9 & $\mathbf{2 4 / ( 7 . 8 )}$ \\
\hline Hypocrisy of/ Reason for One-Nigeria & 5 & 7 & 11 & $\mathbf{2 3 / ( 7 . 4 )}$ \\
\hline Court Updates/Appearances & 5 & 4 & 5 & $\mathbf{1 4 / ( 4 . 5 )}$ \\
\hline Total & $\mathbf{9 2}$ & $\mathbf{1 0 4}$ & $\mathbf{1 1 2}$ & $\mathbf{3 0 9 / ( 1 0 0 \% )}$ \\
& $(\mathbf{2 9 . 8 \% )}$ & $\mathbf{( 3 4 \% )}$ & $(\mathbf{3 6 . 2 \%})$ & \\
\hline
\end{tabular}

Two main areas were outstanding: reporting incompetence and raising the alarms. Analysis also shows that the websites feature counter reporting against unfavourable information from anti-Biafra elements, or expression of dissatisfaction over unfavourable reporting of the media or lack of it. Others include information relating to ineffective representation of Biafran politicians, information on the true nature of IPOB leadership and the adroitness of Nnamdi Kanu, and information on why Nigeria does not want Biafra to be independent. The websites were also used to update the court cases of IPOB activists held in custody.

Significantly, the result suggests that reports analysing the systemic failures of political culture in Nigeria were prominent. Across the three websites, analysis demonstrates that interpretations of events within Nigerian bureaucratic politics feature areas of weaknesses and failures, arguably, suggesting the tendency to frame Nigeria as a failed State. Issues of abuse of office featured prominently and consistently in the communicative discourses as well as framing of President Buhari as an incompetent leader. Example: "The Nigerian Bureau of Statistics (NBS) says the total number of Nigerians who became unemployed within the first and second quarter of 2016 now stands at 2.6 million. This brings the total freshly unemployed persons in the economy to a record high of 4,580,602, since President Muhammadu Buhari took office in May 2015" (BiafraTelegraph, June 2016). This article is supported by a photograph presenting President Buhari as someone without brains (suggesting that he lacks intelligence and skills of governance).

Activists gather news reports or opinion articles published in the mainstream media that analysed weaknesses, abuse of office or incompetence of President 
Buhari's government. This approach seems significant in diffusing anti-Buhari sentiments among the adherents of Biafra and also builds a radical understanding of why Biafra independence is the key. In what Allam (2014) calls repertoire of "virtual dissidence", the weaknesses of public authorities and political structures of a country could be used as a locus of a struggle, by encouraging collective actions against it in the virtual public spaces of the Internet.

One significant finding of this study is that activists' prominently used the strategy of raising the alarm as useful mechanism to communicate primary collective concerns, which also represents an effective repertoire of resistant communication practice against military repression. With the affordances of digital technologies, alarms are sometimes supported with graphic photos or videos of military brutality (Figure 1). While it is possible that some of these alarms have the tendency of being untrue as they could be based on rumours, fear and distrust arising from the repressive approach of the Nigerian government, this strategy enabled the Movement to provoke human rights discourse within and beyond Nigeria and appeals to the ideological and emotional sentiments of its constituent. By circulating graphic evidence of military attacks and killing of members, the websites serve as a reference point for human rights organisations including Amnesty International. Activists first raised the alarm of the disappearance of their leader when he was first arrested and claimed the Nigerian government could not have agreed to having him in custody if activists had not circulated intelligence reports about his arrest online (Tochukwu, 2015). Another prominent alarm was raised to alert the world on the increasing disappearance and killing of supporters by the Nigerian military. Social Movement scholars have used the concept of the repertoire of contention to denote various means by which people engage in oppositional discourse against the status quo. A repertoire comprises what people know they can do when they want to oppose a public decision they consider unjust or threatening (Della Porta, 2013). In the definition developed by Charles Tilly, the repertoire of contention includes "a whole set of means a group has for making claims of different types on different individuals" (Della Porta, 2013). In a political environment, activists employ a certain form of action considered appropriate to express their objectives. For the IPOB Movement, the repressive character of the Nigerian government earns it certain kinds of authority over its claims of victimhood. Reports consistently showed overwhelming outrage within the Movement's constituency over the manner in which unarmed peaceful protesters are killed in their numbers and sometimes thrown in the sea or left in the bush without any investigation (Amnesty International, 2016; Precious, 2016). 
Figure 1. One of the Graphic Evidence of Torture to Support Alarms PICTURE: PRO-BIAFRANS STRANGLED BY NIGERIAN ARMY

O AT 02:20:00 $=$ AFRICA, FEATURED, WORLD NEWS,

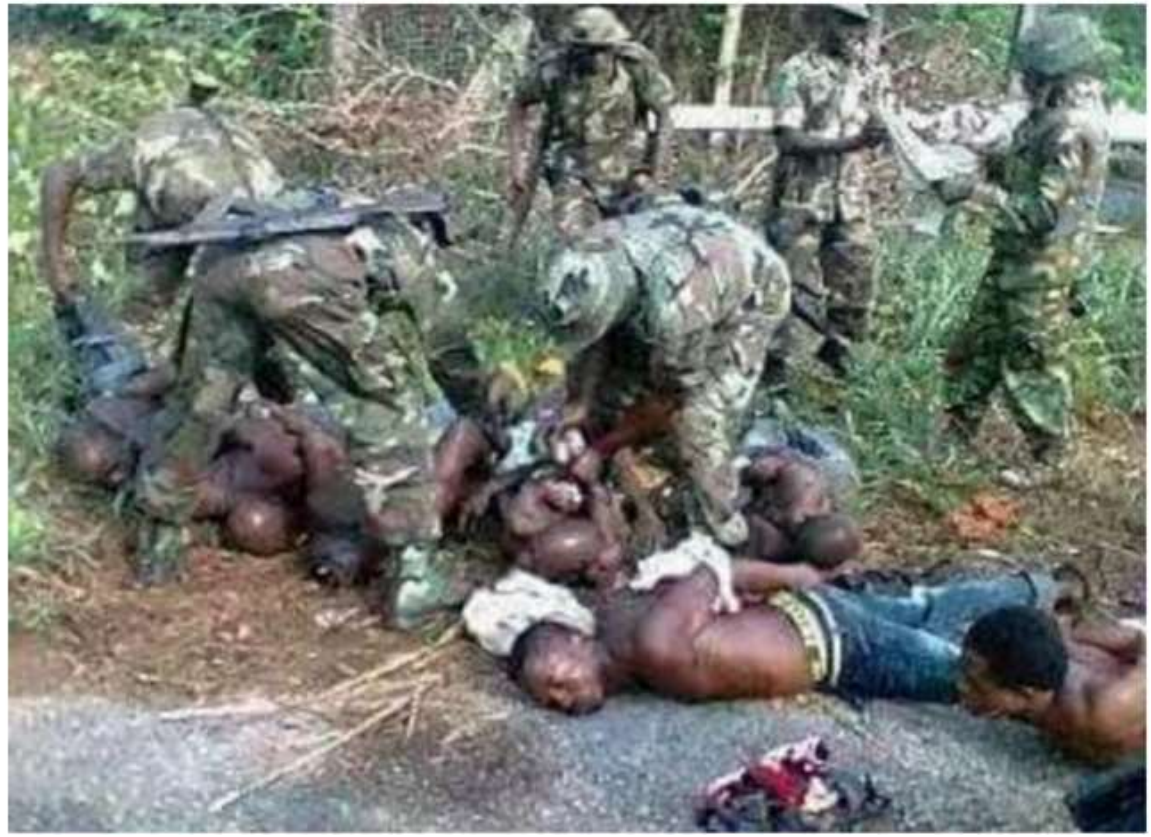

Source: Biafra Telegraph.

Activists use alarms to give new information over unfolding events. They can get classical information that helps them overcome the repressive character of government. When this is the case, activists are encouraged to flood the Internet with claims that will put Nigerian government or concerned person in the defence. Example includes: (1) "Biafra: Mark Zuckerberg sponsored by Buhari to thwart Biafra restoration" (Ogbu, 2016), (2) "EXCLUSIVE: Nigerian Lady Writes Mark Zuckerberg Via DHL, Accuses Facebook of Helping Buhari to Crackdown on Opposition Voices in Nigeria" (BiafraHerald, 2016a), (3) "Information from a reliable source has revealed that MTN Telecommunication Company has joined alliance with the Nigerian government to track down all phone calls and text messages of IPOB members and other genuine Pro-activists working tirelessly for the restoration of Biafra" (Alagba, 2016). These reports arise from fear that the Nigerian government could use the CEO of Facebook or the MTN network to track down activists. Before this, they have raised the alarm that the Nigerian security agencies are tracking and arresting activists through their mobile network. Again, report also goes that the Movement's account was deleted on Facebook platform soon after the CEO visited President Buhari. In some cases, activists are encouraged to stop using the MTN network. In a very creative way, activists used the tactics of alarm to counter anti-Biafran reports, lack of media coverage and media conspiracy on Biafran Movement. 


\section{Action and Mobilisation: Using the Web as Effective Counter-Discourses}

Our result also shows that IPOB Movement appropriated the websites to develop counter-hegemonic praxis aimed at prompting action and mobilise support within and beyond Nigeria society. Table 3 has a summary of variables under action and mobilisation.

Table 3. Thematic Components of Action \& Mobilisation * IPOB Websites Cross Tabulation

\begin{tabular}{|l|c|c|c|c|}
\hline & \multicolumn{3}{|c|}{ IPOB Websites } & \multirow{2}{*}{ Total/(\%) } \\
\cline { 2 - 4 } & $\begin{array}{c}\text { Biafran } \\
\text { Telegraph }\end{array}$ & $\begin{array}{c}\text { Biafran } \\
\text { Herald }\end{array}$ & $\begin{array}{c}\text { Biafran } \\
\text { Times }\end{array}$ & \\
\hline $\begin{array}{l}\text { Mobilising International } \\
\text { Support/Awareness }\end{array}$ & 23 & 28 & 31 & $\mathbf{8 2} /(\mathbf{2 8 . 5})$ \\
\hline $\begin{array}{l}\text { Motivation Action/Unity of } \\
\text { Purpose }\end{array}$ & 16 & 24 & 30 & $\mathbf{7 0 / ( 2 4 . 3 )}$ \\
\hline $\begin{array}{l}\text { History \& Progress of } \\
\text { Movement }\end{array}$ & 14 & 26 & 13 & $\mathbf{5 3 / ( 1 8 . 4 )}$ \\
\hline Referendum/Restructuring & 19 & 8 & 5 & $\mathbf{3 2 / ( 1 1 . 1 )}$ \\
\hline Literal Linkages & 6 & 14 & 8 & $\mathbf{2 8 / ( 9 . 7 )}$ \\
\hline Protest Match & 11 & 6 & 6 & $\mathbf{2 3 / ( 8 )}$ \\
\hline Total & $\mathbf{8 9}$ & $\mathbf{1 0 6}$ & $\mathbf{9 3}$ & $\mathbf{2 8 8 / ( 1 0 0 )}$ \\
\hline
\end{tabular}

Of particular interest are variables, which show that $28.5 \%$ of publications either targeted towards mobilising international support or motivated connective action within Movement's constituents. There is better opportunity for visual connection between Movement's action and the actions of its opponents. Specifically, the analysis focuses on the text that communicates or proposes action and initiatives aimed at achieving specific actions. For example, actions such as motivating activists to sign and share petitions; to tweet evidence of human rights abuses to international stakeholders; announcing or scheduling protest marches, updating the Movement's action plan/progress of struggles etc., are consistent on the websites. In all of these, a tactical mix of alarms and outrage with emotional resources provided a radical atmosphere, which allowed for the contestation of issues, positions and approaches of the Nigerian government to the activists.

The analysis also suggests that communication reinforced internal cohesion by focusing on items that motivate activists to action. Communication focused on the main purpose of the struggle and why activists should not be distracted by antiBiafran elements. As part of educating prospective supporters, the history and progress of the Movement are consistently analysed, notwithstanding some framing tactics that could potentially be untrue. For example, articles such as: "Let Biafra Go, Donald Trump Sends Strong Message to Buhari" (Igbonews, 2016), or "Biafra: if the people of Biafra want Republic of Biafra, it will be a reality during my administration" - Donald Trump (BiafraHerald, 2016b). Communication such as this boggles the mind but also encourages pro-Biafran supporters to hope for Biafra restoration. The IPOB is one of the groups that organised a solidarity rally for Donald Trump after winning the US elections. Their action is in the belief that he would recognise their independent Movement. Many discourses on the web 
tend to give hope to Biafran independence supporters that Trump has assured the IPOB that he will support their Movement to ensure the reality of a Biafran state. This might just be the imagination of a few actors to raise the hope of participants. In what Castells (2009) calls "practice of spin" - formatting messages to bring about most interesting biases that resonate with supporters, the Internet knit together comments and opinions that could sustain a struggle. During the antiWorld Trade Organisation, Van Laer and Van Aelst (2010) showed that activists used the web to disseminate opinions, videos, audio, text and photos, enabling activists to provide coverage and putting up analysis and context to counterbalance the poor US corporate media coverage of the WTO meeting. This analysis focuses on communications taking place on the web and generally examined how such communication supports the cause of Biafra Independence. Significantly, not much information focused on referendum or restructuring, as this only accounted for $11 \%$. This, arguably, suggests that although the Movement presents referendum as major demands, there is no coordination in articulating such demands on its websites. Communications are extravagantly focused on varied issues and do not follow any consistent logic. The analysis notes about $9.7 \%$ of communications literally linking the Movement to other freedom fighters within and outside Nigeria (for example, Movement for the Independence of southern Ambazonia in Cameroon, Niger Delta Avengers, Adaka Biafra Marine Commandos etc.).

\section{Communicating Injustice: Trolling Mechanism and Radical Communication}

The third category is the Injustice frame. Our analysis shows that the Movement used the websites to report and condemn various forms of injustices meted on the activists and their constituents. Injustice is at the core of social Movements' repertories and the Internet has brought the greater possibilities for victims of injustice to mobilise collective outrage and cause sympathy by serving as a link to both organised and dispersed actors in processes of social mobilisation. In this study, as shown in Table 4, there are five variables under which injustice frames were analysed. Significantly, reports focus mainly on human rights abuses (34.1\%), the dictatorial culture of the Nigerian government and the suppression of dissent voice by President Buhari (30.6\%), and injustices relating to Fulani Herdsmen killing of innocent farmers across the country with relative inaction towards tackling it by the Nigerian government (17.2\%).

Of significant interest also is that injustices specifically focusing on the marginalisation only accounted for $7.3 \%$. This, again, shows lack of coherent communication logic that brings out clearly the Movement's main issues. It is clear that the Internet only reinforced the lived reality of the people and help them visualise issues that resonate with them. Essentially, people are just fed up with their situation and have decided to alter the condition by joining the Movement rather than the Internet being a causal factor.

Significant use of human rights narratives has become critical elements of social Movement repertoire, especially in the developing world (Osaghae, 2008). On the websites, reports on the arrest and killing of IPOB activists are consistent, including reactions from the International community and rights groups. Digital 
media platforms circumvent government's ability to block some information from getting to the public sphere. With digital media tools on the hands of activists, protest Movements and other activities of the organisation are sometimes livestreamed on social media and posted on websites, which attracts widespread attention to the Movement. Such videos are sources of reference for mainstream media journalists. Such graphic evidence provides justification and organising principles that bring coherence to the idea of discrimination, inequalities and justice within the Nigerian political system.

Table 4. Thematic Components of Injustice * IPOB Websites Cross Tabulation

\begin{tabular}{|l|c|c|c|c|}
\hline \multirow{2}{*}{} & \multicolumn{3}{|c|}{ IPOB Websites } & \multirow{2}{*}{ Total/(\%) } \\
\cline { 2 - 4 } & $\begin{array}{c}\text { Biafran } \\
\text { Telegraph }\end{array}$ & $\begin{array}{c}\text { Biafran } \\
\text { Herald }\end{array}$ & $\begin{array}{c}\text { Biafra } \\
\text { Times }\end{array}$ & \\
\hline Human Right Abuse & 30 & 24 & 25 & $\mathbf{7 9 / ( 3 4 . 1 \% )}$ \\
\hline Dictatorship/Suppression of Dissent Voice & 23 & 27 & 21 & $\mathbf{7 1 / ( 3 0 . 6 \% )}$ \\
\hline Allowing Herdsmen Terrorism & 22 & 11 & 7 & $\mathbf{4 0 / ( 1 7 . 2 \% )}$ \\
\hline Divide \& Rule/ Prejudice & 6 & 4 & 15 & $\mathbf{2 5 / ( 1 0 . 8 \% )}$ \\
\hline Marginalisation & 6 & 3 & 8 & $\mathbf{1 7 / ( 7 . 3 \% )}$ \\
\hline Total & $\mathbf{8 7}$ & $\mathbf{6 9}$ & $\mathbf{7 6}$ & $\mathbf{2 3 2 / ( 1 0 0 \% )}$ \\
\hline
\end{tabular}

In communicating different forms of injustices, our analysis identified trolling mechanism as a factor, which may have potentially walked the Movement to the frontline of political discourse in Nigeria. The term "trolling" has recently changed to mean not only the provocation of Internet users but the abuse of them too (Bishop, 2014). Trolling describes the increasing spate of unethical behaviours in the Internet community. This includes flaming, profanity, insults and deception. Research has shown that cyber- trolling is a direct manifestation of everyday sadism (Buckels, Trapnell, \& Paulhus, 2014). There is evidence to suggest that the IPOB activists manifest their everyday frustration in their publications. Our analysis shows high tendencies of communication being abusive or ultimately insulting or deceptive. We noted some examples:

1. "Mbaka is now sabotaging indigenous people of Biafra efforts at freedom and restoration of Biafraland. As soon as Aisha, the girl raped by Buhari visited him in his adoration shrine, Mbaka like Balaam raised several devilish alters against Biafra protesters and IPOB leadership. It should be recalled that the sole administrator of [the] Islamic Republic of Nigeria released 20 billion nairas to the media, individuals and clergy to blackmail the Biafra struggle. Mbaka has as usual eaten the food sacrificed to demons and is now playing the harlot" (Orji, 2015).

2. "How the Child rapist Buhari Is Trying to Use Nigerian Senate to Resurrect His Infamous Decree 4" (BiafraTimes, 2015).

Comments like these suggest the level of provocative communication against those who may have not supported the group in one way or another. The data suggests a tendency towards user-generated-racism - a form of communication that attempts to demonise everything and everybody except that which supports Biafran discourse. Social Movements in Africa tend to take 
similar character, as communication is generally antagonistic and illogical. People are more likely to communicate their frustrations using uncivilised words. However, a repertoire of disobedient actions tends to attract more attention and reactions, especially in the context of Nigeria. We argue that this style of communication may have been responsible for the kind of attention received by the Movement. Considering the fact that Nigerian government is less responsive to conflict early warning signs until inconsequential situation becomes a full-blown conflict, transgressive expressions may have become a tactical repertoire that brought the Movement to public knowledge while also, appeared to have prevented the more nuanced individuals from participating or identifying with the struggle. Table 5 shows an overwhelming character of sensationalism in activists' communication on the websites.

Table 5. IPOB Websites * Linguistic Tone Cross Tabulation

\begin{tabular}{|l|c|c|c|c|}
\hline \multirow{2}{*}{ IPOB Websites } & \multicolumn{3}{|c|}{ Linguistic Tone } & \multirow{2}{*}{ Total/(\%) } \\
\cline { 2 - 5 } & Highly Abusive & Partially Abusive & $\begin{array}{c}\text { Generally } \\
\text { sensational }\end{array}$ & \\
\hline Biafran Telegraph & 30 & 34 & 236 & $\mathbf{3 0 0}$ \\
\hline Biafran Herald & 64 & 37 & 199 & $\mathbf{3 0 0}$ \\
\hline Biafran Times & 55 & 21 & 224 & $\mathbf{3 0 0}$ \\
\hline Total & $\mathbf{1 4 9 / ( 1 6 . 6 \% )}$ & $\mathbf{9 2 / ( 1 0 . 2 \% )}$ & $\mathbf{6 5 9 / ( 7 3 . 2 \% )}$ & $\mathbf{9 0 0 / ( 1 0 0 )}$ \\
\hline
\end{tabular}

Benford and Snow (2000) argue that the credibility of collective action frame among Movement's constituent is an important factor in frame resonance. In this argument, the emphasis is not "whether the diagnostic and prognostic claims are factual or valid but whether their empirical referents lend themselves to being read as real indicators of diagnostic claims" (Benford and Snow, 2000, p. 620). In other words, is there something out there that can be pointed to as evidence of the claims embedded in the framing? The slices of evidence on the websites is an important resonance that appeals to some segments of the prospective or actual adherents of Biafra. According to Castells (2015), the Internet turns raw responses into a Movement of political importance, by facilitating the trajectory from outrage to hope and to action. IPOB activists invoked the narrative of human rights to build, articulate and mobilise pro-Biafra sentiments, with a tactical mix of alarms and trolling mechanisms. Bishop (2014) argues that for long time the mass media organisations have created a demonised transgressive character to increase the visibility of their audiences living situation as a way of being responsible to their audiences. In the millennial digital communication practices, this style of reporting is taking permanent roots. In the context of the IPOB activists, trolling (arguably) becomes one way of expressing the lived reality of frustrations and grievances with the target of building radical followership and attracting mass media coverage. 


\section{Identity}

Another area of communication on the websites stresses value differentiation and resourcefulness of the "Biafrans". Activists used items expressing cultural identity, ethnic identity and socioeconomic identity of the Biafrans to define the boundaries between "us" and "them"; making a case for a new republic that will be the economic hub of the world. In particular, items expressing religious/ethnic identity take prominence in the three websites, accounting for $49.3 \%$ of the total reports under this category. Ethnic and religious consciousness are factors that have affected Nigeria as a country. This analysis shows expressions communicating how Biafrans have been discriminated, marginalised or attacked based on their religious and ethnic identity. And so, with Biafra the value orientation of the Biafrans as Christians would subsist.

Table 6. Thematic Components of Identity/Culture * IPOB Websites Cross Tabulation

\begin{tabular}{|l|c|c|c|c|}
\hline & \multicolumn{3}{|c|}{ IPOB Websites } & \multirow{2}{*}{ Total/(\%) } \\
\cline { 2 - 4 } & Biafran Telegraph & Biafran Herald & Biafran Times & \\
\hline Religious/Ethnic Identity & 16 & 6 & 13 & $\mathbf{3 5} /(\mathbf{4 9 . 3})$ \\
\hline Political/Economic Identity & 7 & 9 & 2 & $\mathbf{1 8 / ( 2 5 . 4 )}$ \\
\hline Cultural Identity & 9 & 5 & 4 & $\mathbf{1 8 / ( 2 5 . 4 )}$ \\
\hline Total & $\mathbf{3 2}$ & $\mathbf{2 0}$ & $\mathbf{1 9}$ & $\mathbf{7 1 / ( 1 0 0 )}$ \\
\hline
\end{tabular}

Furthermore, the political and economic strength of Biafrans were reported. This emphasises their entrepreneurial ability and resourcefulness. This argument is mostly made in defence of the propaganda that an independent Biafra will be a disaster. Reports tend to creating a strong sense of identity and educating the people that an Independent Biafra will mean freedom, productivity and hard work. Other reports stress the cultural differentiation of the Biafran people, that is value differentiation (Table 6). Social Movement scholars have emphasised that building a sense of identity is a sine qua non for Movement's collective action. With strategic framing, Movements define grievance between "us" and "them" in the structure of conflicts and allies and draw on collective identity frames to shape their mobilisation efforts since a Movement requires solidarity to act collectively, "constructing identities around its claims is one way of doing so" (Tarrow, 2011). The IPOB activists draw on the cultural, religious, economic and political values to construct a Biafran identity.

\section{Conclusion}

This paper has examined the communicative practices of the IPOB Movement on its three main websites. The results suggest that the Movement's web serves as an alternative media platform wherein the invention and circulation of counter-discourses on Biafra as well as Nigeria's politics is permissible. With a strategic mix of alarm and outrage, the IPOB mobilised oppositional interest to the celebrated atrocities of security agents that serve to 
dramatize and render more salient the dictatorial and arbitrary nature of Buhari administration. It is argued that the choice of the repertoire of action is a function of the relationship between the object of claims, the claimant and the environment it is facing: political institutions, elites, mass media, ad-hoc or alternative public space (Teune, 2006). Through a varying degree of radical publication, the IPOB appropriated its web resources to produce a repertoire that aims to raise expectations, arouse feelings, manifest pressures on politicians and government and amplify frames that appear to resonate with their prospective or actual adherents. There is a significant evidence of counterhegemonic publications that are not just correcting misinformation or misrepresentation of the media, government or its agents, but also focused on the failures of leadership in Nigeria. Specifically, the websites (1) provided information relevant for micro mobilisation; (2) serve as a hub for native reporting and radical content production, and (3) serve as a channel for documenting graphic evidence of victimhood. Significant publications focused on mobilising international supports, drawing attention to human rights abuses in Nigeria and the arbitrary nature of President Buhari's government. The study notes a varying degree of focus in the main agenda of the Movement, which is mobilising support for referendum to determine Biafran union with Nigeria. This agenda was not appropriately communicated. Issues were varied and inconsistent, casting doubt on the main agenda of the Movement. However, by focusing largely on the failures of the Nigerian State, human rights abuse and general incompetence and abuse of office, the Movement used the web to create an alternative vision of promoting Nigerian democracy than aiming for an independent Biafra. Moreover, the Movement's radical expressions and investigative role around public officials has further deepened political awareness and expressions in Nigeria's public sphere.

Some potential limitations are noted, as they also suggest direction for future study. First, given that the study is based on the Movement's three main websites, an expansive measure that includes all other channels of Movement's communication can test the extent the Movement is able to articulate its objective on the Internet. Secondly, future work can further test whether the variables identified in this study contribute to the Movement's mobilisation success.

\section{References}

Adu, P. (2016). Qualitative Analysis: Coding and Categorizing Data. NCADE The Chicago School of Professional Psychology.

Alagba, P. I. (2016). Exposing MTN's Alliance with Nigerian Government to Annihilate Biafrans. Retrieved from http://www.thebiafraherald.co.

Akser, M. (2015). Social Movements and their Technologies: Wiring Social Change. London: SAGE Publications.

Allam, N. (2014). Arab Revolutions: Breaking Fear| Blesses and Curses: Virtual Dissidence as a Contentious Performance in the Arab Spring's Repertoire of Contention. International Journal of Communication, 8, 18. 
Amnesty International. (2016). Nigeria: Bullets were Raining Everywhere: Deadly Repression of pro-Biafra Activists. Retrieved from www.amnesty.org.

Atton, C. (2004). An alternative internet. UK: Edinburgh University Press.

Atton, C. (2015). The Routledge Companion to Alternative and Community Media. London: Routledge.

Ben Moussa, M. (2011). The Use of the Internet by Social Movements in Morocco: Implications for Collective Action and Political Change. Concordia University.

Benford, R. D., \& Snow, D. A. (2000). Framing Processes and Social Movements: An Overview and Assessment. Annual Review of Sociology, 26(1), 611-639.

Bennett, W. L., \& Pfetsch, B. (2018). Rethinking Political Communication in a Time of Disrupted Public Spheres. Journal of Communication, 68(2), 243-253.

BiafraHerald. (2016a). EXCLUSIVE: Nigerian Lady Writes Mark Zuckerberg Via DHL, Accuses Facebook of Helping Buhari to Crackdown on Opposition Voices in Nigeria. Retrieved from http://www.thebiafraherald.co.

BiafraHerald. (2016b). BIAFRA: "If the People of Biafra want Republic of Biafra, it will be a Reality During my Administration"-Donald Trump. Retrieved from http://www.thebiafraherald.co.

BiafraTelegraph. (2016, June). Nigreia: 4.58 Million Nigerians have Lost their Jobs under Bubari. Retrieved from http://www.thebiafratelegraph.co.

BiafraTimes. (2015). How the Child rapist Buhari is Trying to use Nigerian Senate to Resurrect his Infamous Decree 4. Retrieved from https://bit.ly/2rk5hql.

Bishop, J. (2014). Representations of "Trolls" in Mass Media Communication: A Review of Media-texts and Moral Panics Relating to "Internet Trolling". International Journal of Web Based Communities, 10(1), 7-24.

Boykoff, J. (2006). Framing Dissent: Mass-media Coverage of the Global Justice Movement. New Political Science, 28(2), 201-228.

Boykoff, J. (2013). The Suppression of Dissent: How the State and Mass Media Squelch US American Social Movements. New York: Routledge.

Boyle, M. P., McLeod, D. M., \& Armstrong, C. L. (2012). Adherence to the Protest Paradigm: The Influence of Protest Goals and Tactics on News Coverage in US and International Newspapers. The International Journal of Press/Politics, 17(2), 127-144.

Buckels, E. E., Trapnell, P. D., \& Paulhus, D. L. (2014). Trolls just want to have Fun. Personality and Individual Differences, 67, 97-102.

Castells, M. (2009). Communication Power. New York: Oxford. University Press.

Castells, M. (2015). Networks of Outrage and Hope: Social Movements in the Internet Age. UK: John Wiley \& Sons.

Cissel, M. (2012). Media Framing: a comparative content analysis on mainstream and alternative news coverage of Occupy Wall Street. The Elon Journal of Undergraduate Research in Communications, 3(1), 67-77.

Conover, M. D., Davis, C., Ferrara, E., McKelvey, K., Menczer, F., \& Flammini, A. (2013). The Geospatial Characteristics of a Social Movement Communication Network. PloS One, 8(3), e55957.

Dahlberg, L. (2007a). Rethinking the Fragmentation of the Cyberpublic: From Consensus to Contestation. New Media \& Society, 9(5), 827-847.

Dahlberg, L. (2007b). The Internet and Discursive Exclusion: From Deliberative to Agonistic Public Sphere Theory. In L. Dahlberg, \& E. Siapera (Ed.), Radical Democracy and the Internet (pp. 128-147). London: Palgrave Macmillan.

Dahlberg, L., \& Siapera, E. (2007). Radical Democracy and the Internet: Interrogating Theory and Practice. London: Palgrave Macmillan. 
Dahlgren, P. (2005). The Internet, Public Spheres, and Political Communication: Dispersion and Deliberation. Political Communication, 22(2), 147-162.

Della Porta, D. (2013). Repertoires of contention. The Wiley-Blackwell Encyclopedia of Social and Political Movements. https://doi.org/10.1002/9780470674871.wbe spm178.

Downey, J., \& Fenton, N. (2003). New Media, Counter Publicity and the Public Sphere. New Media \& Society, 5(2), 185-202.

Downing, J. D. (2000). Radical Media: Rebellious Communication and Social Movements. California, London and New Delhi: SAGE Publications.

Earl, J., \& Garrett, R. K. (2017). The New Information Frontier: Toward a More Nuanced View of Social Movement Communication. Social Movement Studies, 16(4), 479-493.

Enjolras, B., Steen-Johnsen, K., \& Wollebæk, D. (2013). Social Media and Mobilization to Offline Demonstrations: Transcending Participatory Divides? New Media \& Society, 15(6), 890-908.

Evans, E. M. (2016). Bearing Witness: How Controversial Organizations Get the Media Coverage They Want. Social Movement Studies, 15(1), 41-59.

Fuchs, C. (2010). Alternative Media as Critical Media. European Journal of Social Theory, 13(2), 173-192.

Garrett, R. K. (2006). Protest in an Information Society: A Review of Literature on Social Movements and new ICTs. Information, Communication \& Society, 9(2), 202-224.

Gerbaudo, P. (2018). Tweets and the Streets: Social Media and Contemporary Activism. London and New York: Pluto Press.

Gimmler, A. (2001). Deliberative Democracy, the Public Sphere and the Internet. Philosophy \& Social Criticism, 27(4), 21-39.

Hands, J. (2007). Between Agonistic and Deliberative Politics: Towards a Radical Edemocracy. In Radical Democracy and the Internet (pp. 89-107). London: Springer.

Harlow, S. (2012). Social Media and Social Movements: Facebook and an Online Guatemalan Justice Movement that moved Offline. New Media \& Society, 14(2), 225-243.

Harlow, S., \& Harp, D. (2013). Alternative Media in a Digital Era: Comparing News and Information use among Activists in the United States and Latin America. Communication \& Society, 26(4), 25-51.

Igbonews. (2016). Let Biafra Go, Donald Trump Sends Strong Message to Buhari. Retrieved from http://igbonews.co.uk.

Jofré, D. (2017). Social Movements and Media: Unravelling the Communication Practices of Environmental SMOs in Chile (PhD Dissertation). University of Glasgow, UK.

Kellner, D. (1999). Globalisation from below? Toward a Radical Democratic Technopolitics. Angelaki: Journal of the Theoretical Humanities, 4(2), 101-113.

Leung, D. K., \& Lee, F. L. (2014). Cultivating an active online counterpublic: Examining usage and political impact of Internet alternative media. The International Journal of Press/Politics, 19(3), 340-359.

Lievrouw, L. (2011). Alternative and Activist New Media. Malden, MA: Polity Press.

Lievrouw, L. A. (2006). Oppositional and Activist New Media: Remediation, Reconfiguration, Participation. Paper presented at the Proceedings of the 9th Conference on Participatory Design: Expanding Boundaries in Design, Volume 1. 
Mattoni, A. (2017). A Situated Understanding of Digital Technologies in Social Movements. Media Ecology and Media Practice Approaches. Social Movement Studies, 16(4), 494-505.

Mouffe, C. (2000). Deliberative Democracy or Agonistic Pluralism. Social Research, 66(3), 745-758.

Ogbu, C. (2016). Biafra: Mark Zuckerberg Sponsored By Buhari to Thwart Biafra Restoration. Retrieved from http://www.thebiafraherald.co.

Onuoha, G. (2018). Bringing "Biafra" back in: narrative, identity, and the politics of non-reconciliation in Nigeria. National Identities, 20(4), 379-399.

Orji, B. (2015). Mbaka and his Doctrine of Balaam. Retrieved from https://bit.ly/2Q6D MiR.

Osaghae, E. E. (2008). Social Movements and Rights Claims: The Case of Action Groups in the Niger Delta of Nigeria. Voluntas: International Journal of Voluntary and Nonprofit Organizations, 19(2), 189.

Platon, S., \& Deuze, M. (2003). Indymedia Journalism: A Radical Way of Making, Selecting and Sharing News? Journalism, 4(3), 336-355.

Poell, T. (2014). Social Media and the Transformation of Activist Communication: Exploring the Social Media Ecology of the 2010 Toronto G20 protests. Information, Communication \& Society, 17(6), 716-731.

Poell, T., \& Borra, E. (2012). Twitter, YouTube, and Flickr as Platforms of Alternative Journalism: The Social Media Account of the 2010 Toronto G20 Protests. Journalism, 13(6), 695-713.

Precious, E. (2016). The secret murder of Biafrans by the zoo-Nigerian soldiers. Retrieved from http://www.thebiafratelegraph.co/2016/03/the-secret-murder-ofbiafrans-by-zoo.html

Rauch, J. (2007). Activists as Interpretive Communities: Rituals of Consumption and Interaction in an Alternative Media Audience. Media, Culture \& Society, 29(6), 994-1013.

Rodriguez, C. (2000). Civil Society and Citizens Media. Peace Architects for the New Millennium. In K. G. Wilkins (Ed.), Redeveloping Communication for Social Change. Theory, Practice, Power (pp. 147-160). New York, Toronto and Playmouth: Rowman \& Littlefield Publishers, Inc.

Salazar, J. F. (2003). Articulating an Activist Imaginary: Internet as Counter Public Sphere in the Mapuche Movement, 1997/2002. Media International Australia Incorporating Culture and Policy, 107(1), 19-30.

Saldaña, J. (2015). The Coding Manual for Qualitative Researchers. London: SAGE Publications.

Salter, L. (2013). Democracy, New Social Movements, and the Internet: A Habermasian Analysis. In M. Mccaughey, \& M. D. Ayers (Ed.), Cyberactivism (pp. 127-154). London: Routledge.

Sandoval-Almazan, R., \& Gil-Garcia, J. R. (2014). Towards Cyberactivism 2.0? Understanding the use of Social Media and other Information Technologies for Political Activism and Social Movements. Government Information Quarterly, 31(3), 365-378.

Schneider, S. M., \& Foot, K. A. (2004). The Web as an Object of Study. New Media \& Society, 6(1), 114-122.

Stein, L. (2009). Social Movement Web use in Theory and Practice: A Content Analysis of US Movement Websites. New Media \& Society, 11(5), 749-771.

Tarrow, S. G. (2011). Power in Movement: Social Movements and Contentious Politics. UK: Cambridge University Press. 
Teune, S. (2006). Making sense of communication repertoires in the German global justice movements. Paper presented in the Marie Curie Conference and Training Series European Protest Movements since the Cold War: The Rise of a (Trans-) national Civil Society and the Transformation of the Public Sphere after 1945. Retrieved from https://bit.ly/2TGynfR.

Tochukwu, T. (2015). Biafra: Buhari's plans exposed! Retrieved from https://bit.ly/2E $8 \mathrm{cmmp}$.

Tong, J. (2015). The Formation of an Agonistic Public Sphere: Emotions, the Internet and News Media in China. China Information, 29(3), 333-351.

Van Laer, J., \& Van Aelst, P. (2010). Internet and Social Movement Action Repertoires: Opportunities and Limitations. Information, Communication \& Society, 13(8), 1146-1171.

Wall, M. A. (2003). Social Movements and the Net: Activist Journalism goes Digital. In K. Kawamoto (Ed.), Digital Journalism: Emerging Media and the Changing Horizons of Journalism (pp. 113-122). USA: Rowman \& Littlefield Publishers, Inc.

Yung, B., \& Leung, L. Y.-M. (2014). Diverse Roles of Alternative Media in Hong Kong Civil Society: From Public Discourse Initiation to Social Activism. Journal of Asian Public Policy, 7(1), 83-101. 
